\title{
ВКЛАДЫ КНЯЖЕСКИХ ФАМИЛИЙ В МОСКОВСКИЙ ЧУДОВ МОНАСТЫРЬ В XVI-XVII ВЕКАХ: ХРОНОЛОГИЯ И ДИНАМИКА
}

\section{THE CONTRIBUTIONS OF PRINCELY FAMILIES TO THE MOSCOW CHUDOV MONASTERY IN THE $16^{\text {TH }}-17^{\text {TH }}$ \\ CENTURIES: CHRONOLOGY AND DYNAMICS}

\section{A. Sergeev}

Summary: The article is devoted to the determination of the chronology and dynamics of the prince's contributions to the Chudov Monastery. It was found that the time range of contributions covers the 1538-1670 and the largest number fell on the period 1586-1650. The indicated dynamics differs from similar indicators of some other monasteries, in which the largest number of princely deposits was noted in the second third of the 16th century, and in the last decades of the 16th - first 17th centuries there was a noticeable decline. The peculiarity of the dynamics in this case can be explained by the poor preservation of the data on contributions for the first or second third of the 16th century, the loss of most of the data for this period.

Keywords: princes, deposits, synodik, manuscripts, social status, Sovereign's court.
Сергеев Антон Вадимович

К.и.н., Санкт-Петербургский институт истории РАН sergeev1967@inbox.ru

Аннотация: В статье установлено, что временной диапазон вкладов княжеских фамилий в Московский Чудов монастырь охватывает 1538-1670-е гг. и максимальное количество пришлось на период 1586-1650 гг. Указанная динамика отличается от аналогичных показателей ряда других обителей, в которых наибольшее число княжеских вкладов отмечено во второй трети XVI В., а в последних десятилетияX XVI - первых XVII наблюдался заметный спад. Своеоборазие динамики в случае Чудова монастыря можно объяснить плохой сохранностью данных о вкладах за первую-вторую трети XVI в., утратой большей части сведений за этот период.

Ключевые слова: князья, вклады, синодик, рукописи, социальный статус, Государев двор.

(1545/46)г. ЧМ было отведено первое место4. Конечно, свидетельство указанного памятника не следует понимать слишком буквально, тем не менее, можно констатировать, что в официальной церковной иерархии и в общественном мнении ЧМ входил в число наиболее значимых и почитаемых обителей. Его высокий статус подтверждается указанной величиной вклада «вечного поминания», тогда как в провинциальных монастырях (Ростовском Борисоглебском, Толгском и др.) он составлял около 30 руб. [25, с. 53], [26, с. 83]. Подтверждение размера поминального вклада в ЧМ содержится в одном из его памятников [35, с. 40-41]: 28 февраля 1586 г. князь Сава Щербатый дал «по отце своем князе Дмитрие 25 руб., а в 30 руб. дал на себя память своею рукою. И за тот его вклад отца его князя Дмитрея в Чюдове монастыре погребли честно и имя его в братцкой сенаник и во вседневной написали». В СЧМ поминание, Д. Щербатого обеспеченное указанным вкладом, отсутствует. Приведен\footnotetext{
50 руб. [7, с. 56], а в иерархии монастырей, установленной по сообщению Пискаревского летописца в 7054

Автором принято предположение, что присутствие имен тех или иных лиц в монастырском синодике указывает на вклад, сделанный деньгами или вещами, достаточный для «вечного поминания». В главных обителях
}

\footnotetext{
1 OР РНБ. Ф. 550. F.IV.194.

2 Предварительные наблюдения по отмеченным вопросам были сформулированы автором в тезисах [28].

3 Упоминание о вкладной книге есть в Описи хранилища ЧМ 1755 г. [1, с. 73].

4 «В лето 7054-го царь и великий князь Иван Васильевич пожаловал, указал места архимандриту троецкому Сергиева манастыря да кириловскому игумену, да павнутьевскому, да осифовскому: троецкому под чюдовским, а кириловскому под андрониковским, а павнутьевскому под богоявленским на Москве за торгом, а осифовскому под павнутьевским; а преж им мест не бывало» [19, с. 180].
} 
ная запись интересна тем, что прямо называет размер вклада, необходимого для «вечного» поминания в чМ. Он составлял около 50 руб. (в данном случае оказался выше - 55 руб.). Всего князья Щербатые дали в обитель не менее 12 вкладов (Табл. 1. № 27, 40, 41, 48, 68, 69, 73, $74,88,100,101,131)$. ЧМ оставался усыпальницей этой фамилии и в XVIII в. [16, с. 54, 61].

Определив хотя бы приближенно время появления соответствующих записей в СЧМ, можно охарактеризовать динамику (интенсивность) вкладов: когда их давалось больше, а когда меньше. Выяснению дат помогают биографические сведения о лицах, включенных в поминания, сопоставление текста СЧМ с вкладными и поминальными записями тех же фамилий в других обителях. В этом отношении лучше всего установлению времени вкладов способствуют памятники Троице-Сергиева монастыря (ТСМ). Их особенностью является «датированность» большинства записей, что в отдельных случаях позволяет определить и время вклада в ЧМ. «Сравнительно-сопоставительный метод» в данном случае оправдан тем, что вклады обычно делались по умершим родственникам, перед уходом в монастырь и нередко в несколько обителей одновременно [34, с. 311]. Датировке вкладов помогают также указания разрядных, родословных книг, иных памятников. В ряде случаев (Табл. 1. № 3, 47, 76, 135 и др.) автору приходилось ориентироваться на записи соседние с датируемой, для которых время определялось более-менее точно. Следует отметить, что указанный подход в случае СЧМ можно использовать только при отсутствии иных «ориентиров», поскольку, в целом, последовательность записей плохо согласуется с их хронологией. Объясняется это тем, что данный памятник создавался на основе более ранних синодиков. При переписке разновременные поминания «перемешивались», отдельные записи лиц той или иной фамилии «объединялись».

Всего в СЧМ внесено около 136 поминаний с именами лиц 67 княжеских фамилий (Табл. 1) ${ }^{6}$. Для полноты картины автором учитывались не только записи СЧМ, но и сведения о вкладах в Хозяйственных книгах (ХК1586) [35]. Два из них отмечены в динамике (Табл. 1. № 26, 27), а другие, не предполагавшие «вечного» поминания, рассмотрены ниже только в тексте статьи. К сожалению, установить время удалось далеко не для всех вкладов, и немало случаев "датированы» диапазоном лет. Возможно, дальнейшие исследования позволят внести уточнения в предложенную «хронологию». Ограниченный объем настоящей публикации не дает возможности поместить в статье обоснование датировок для каждой записи. Ниже рассмотрены только несколько примеров, иллюстрирующих проделанную работу. При их отборе автор руководствовался следующими критериями: помещены сведения о всех вкладах, не отмеченных в СЧМ, выявленных по иным памятникам, записи, содержащие биографические сведения о лицах княжеских фамилий, неизвестные по другим источникам, поминания, которые удалось датировать более-менее точно и, напротив, случаи, оценки времени вклада по косвенным данным.

Таблица 1

Хронология вкладов княжеских фамилий

в Чудов монастырь ${ }^{7}$

\begin{tabular}{|c|l|l|}
\hline \multicolumn{1}{|c|}{ №та } & \multicolumn{1}{c|}{ Поминание } \\
\hline 1. & $1538-40-$-е & Л.178-178 об. Род княж Андреа Лапин 0боленской. \\
\hline 2. & $1548-60(1560)$ & Л. 174. Кубенских. \\
\hline 3. & $1550-1560$ & Л. 186. Род князей Волконских. \\
\hline 4. & 1550 (?) & Л. 187-187 об. Род князя Феодора Михайловича Ушатого Ерославского. \\
\hline 5. & 1550 & Л. 189. Род князя Никиты Александровича Ростовского. \\
\hline 6. & $1550-1560(1550)$ & Л. 189 об. Род князя Данила Тулупа Ряполовского. Княгиню Марию, княжну Ефросинию. \\
\hline 7. & $1550-1560$ & Л. 190 об. Род Дорогобужской. \\
\hline 8. & 1551 & Л. 177. Род князя Ивана Кубенского. \\
\hline 9. & 1551 & Л. 193 об. Род Бельских князей. \\
\hline 10. & 1552 & Л. 98 об. Род князя Феодора Прозоровскаго. \\
\hline 11. & 1552 & Л. 183-183 об. Род князя Феодора Андреевича Прозоровского. \\
\hline
\end{tabular}

5 Указанные особенности СЧМ охарактеризованы А.И. Алексеевым [3, с. 14].

6 Княжеские фамилии, существовавшие в Московском государстве, охарактеризованы автором в специальной работе [24].

7 В Табл. 1 отмечены номера листов СЧМ и заголовки поминальных записей по публикации А.И. Алексеева [3], кроме № 26, 27. В отдельных случаях для диапазона лет указан в скобках наиболее вероятный год, у сомнительных дат поставлен (?). В № 6, 21, 73, 81, 102, 108 поминания приведены полностью. В круглых скобках помещен текст, зачеркнутый в рукописи. 


\begin{tabular}{|c|c|c|}
\hline № & Дата & Поминание \\
\hline 12. & 1550-е или 1670 (?) & Л. 60. Род Прозоровскых. \\
\hline 13. & $1553-54$ & Л. 178. Род князя Ивана Хованского. \\
\hline 14. & 1560 & $\begin{array}{l}\text { Л. } 128 \text { об. Род князя Симеона Мезецкого. } \\
\text { Л. } 198 \text { об. Род князя Семена Михайловича Мезецкого. }\end{array}$ \\
\hline 15. & 1562 & Л. 187 об. Род княгини Агрипены Сутцкой. \\
\hline 16. & $1565-66(1566)$ & Л. 88 Род князя Ивана Федоровича Троекурова. \\
\hline 17. & $1550-68$ & Л. 112. Род князя Ивана Ростовскова Хохолкова. \\
\hline 18. & 1568 & Л. 186 об. Род Щетининой. \\
\hline 19. & $1568-71$ & Л. 118 об. Род князя Ивана Дмитриевича Белскова. \\
\hline 20. & 1570-e & Л 76. Род князя Петра Даниловича Пронсково. \\
\hline 21. & $1570-\mathrm{e}$ & Л. 68. Род по казенном диаке Непеи и княгине Анастасеи Нохтевы. Анастасею. \\
\hline 22. & $1572-1580$ & Л. 178. Род князя Андреа Холмского. \\
\hline 23. & 1578 & Л. 78. Род князя Емельяна Тюфякина. \\
\hline 24. & 1586 & Л. 93 об. Род князя Ивановы княгини Петровича. Княгини Марию. \\
\hline 25. & 1586 & Л. 141. Род князя Василия Васильевича Мосальскова. \\
\hline 26. & 1586 & Вклад Рождественского монастыря старицы княгини Фетиньи Барятинской. \\
\hline 27. & 1586 & Вклад Савы Дмитриевича Щербатого по отце. \\
\hline 28. & 1589 & Л. 139. Род князя Петра Ивановича Хворостинина. \\
\hline 29. & 1590 (?) & Л. 103 об. Род князя Андреевой княгини Ивановича Стригина. \\
\hline 30. & 1595 & Л. 89. Род князя Петра Лобанова Ростовского. \\
\hline 31. & $1595-1602$ & Л. 90. Род князя Ивановы княгини Ирины Засекина. \\
\hline 32. & 1598 & Л. 133. Род князя Семена Михайловича Ростовского. \\
\hline 33. & $1570-1600(1600)$ & Л. 125. Род князя Ивана Овчинина. \\
\hline 34. & $1600-e$ & Л. 67 об. Род княгини Анастасеи Туренины. \\
\hline 35. & $1580-1600$ & Л. 72-72 об. Род князя Никиты Васильевича 0боленского Тюфякина. \\
\hline 36. & $1580-1600$-e & Л. 74 об. Род князя Михаловы княгини Петровича Репнина. \\
\hline 37. & $1595-1600$ & Л. 75 об. Род князя Александра Ивановича Шуйского. \\
\hline 38. & $1600-e$ & Л. 198 об. Род Охлябин. \\
\hline 39. & 1600 (?) & Л. 60 об. Род Курлятевых. \\
\hline 40. & 1600-e & Л. 75 об. Род князя Ивана Григорьевича Щербатого. \\
\hline 41. & $1600-e$ & Л. 76. Род князя Меркурия Александровича Щербатого. \\
\hline 42. & 1600 & $\begin{array}{l}\text { Л. } 84 . \text { Род князя Феодора Михайловича Ростовскова Лобанова. } \\
\text { Л. } 124 \text { об. (Род князь Федора Михайловича Ростовского Лобанова. Феодосия) }{ }^{8} .\end{array}$ \\
\hline 43. & 1602 & Л. 86. Род князя Федора Михайловича Трубетцкова. \\
\hline 44. & 1602 & Л. 91. Род князя Ивана Михайловича Глинскова. \\
\hline 45. & $1600-1604$ & Л. 97. Род князя Никитины княгини Васильевича Оболенскаго Тюфякина. \\
\hline 46. & $1600-\mathrm{e}$ & Л. 106 об. Род княгини Анастасеи Туренины. \\
\hline 47. & $1600-e$ & Л. 107. Род князя Феодора Андреевича Звенигородцкова. \\
\hline 48. & $1600-e$ & Л. 148 об. Род князя Иосифа Михайловича Щербатого. \\
\hline 49. & 1605 (?) & Л. 138 об.-139. Род князя Петровы княгини Михайловича Шеховского. \\
\hline 50. & $1607-1608$ & Л. 82 об. Род князя Петра Буйносова Ростовского. \\
\hline
\end{tabular}

8 Запись зачеркнута в рукописи (ОР РНБ. Ф. 550. F.ІV.194. Л. 124 об. (129 об.)). 


\begin{tabular}{|c|c|c|}
\hline № & Дата & Поминание \\
\hline 51. & $1608-1609$ & Л. 44. Род князя Александра Даниловича Приимкова Ростовского. \\
\hline 52. & $1610-20$ & Л. 57. Род князя Ивана Ивановича Дашкова. \\
\hline 53. & $1608-1610$ & Л. 43. Род князя Стефана Ивановича Гагина. \\
\hline 54. & 1616 & Л. 58 об. Род князя Юрья Петровича Ушатова. \\
\hline 55. & $1606-1615$ & Л. 59. Род князя Федора Пронсково. \\
\hline 56. & $1606-1615(1606)$ & Л. 59 об. Род князя Михайла Петровича Катырева Ростовского. \\
\hline 57. & 1611 & Л. 133. Род князь Ивановы княгини Михайловича Катырева. \\
\hline 58. & 1611 & Л. 92. Род боярина и дворецкова князя Василия Михайловича Мосальскова. \\
\hline 59. & $1611-15(1611)$ & Л. 92 об. Род князя Василия Михайловича Лобанова Ростовского. \\
\hline 60. & $1600-1618$ & Л. 52. Род князя Андрея Трубецкого. \\
\hline 61. & 1618 & Л. 54 об. Род князя Андрея Трубецкого. \\
\hline 62. & $1615-22$ & Л. 88 об. Род князя Борисовы княгини Никитича Приимкова Ростовского. \\
\hline 63. & $1617-21$ & Л. 114 об. Род князя Григорья Васильевича Тростенскова. \\
\hline 64. & 1620 & $\begin{array}{l}\text { Л. 30. Род князя Никиты Андреевича Волконьского. } \\
\text { Л. } 135 \text { об. Род князя Никиты Андреевича Волконсково. }\end{array}$ \\
\hline 65. & 1620 -e (1626) & Л. 136 об. Род князя Василья Васильевича Тюфякина. \\
\hline 66. & $1620-22$ & Л. 125. Род князь Бориса Никитича Приимкова Ростовского. \\
\hline 67. & 1622 & $\begin{array}{l}\text { Л. } 28 \text { об. Род князя Федора Ивановича Мстиславского. } \\
\text { Л. } 31 \text { об. Род князя Федора Ивановича Мстиславского. } \\
\text { Л. } 71 \text { об. (Род князя Федора Ивановича Мстиславского. Князя Феодора)ํ. }\end{array}$ \\
\hline 68. & $1622-26$ & Л. 144. Род князя Феодора Лукича Щербатова. \\
\hline 69. & Д0 1626 & Л. 101. Род князя Кондрата Щербатого. \\
\hline 70. & 1626 & Л. 31 об. Род Тростеньских. \\
\hline 71. & $1627-44(1627)$ & Л. 120. Род князя Феодора Ситцкова. \\
\hline 72. & $1626-27$ & Л. 32 об. Род боярина князя Ивана Васильевича Голицына. \\
\hline 73. & $1627-28$ & $\begin{array}{l}\text { Л. } 62 \text { об. Род Якова Лукича Щербатого. Князя Иякова убиенаго, князя Феодора, князя Никиту преставися } \\
136 \text { году сентября в } 1 \text { день. }\end{array}$ \\
\hline 74. & 1620-e & Л. 55. Род князя Феодора Щербатого. \\
\hline 75. & $1626-28$ & Л. 102. Род князя Василья Пронскова. \\
\hline 76. & 1614-30-e & Л. 131. Род князя Ивановы княгини Хворостинина княгини Устинию Васильевны. \\
\hline 77. & 1626 & Л. 149. Род Долгоруких. \\
\hline 78. & 1628 & Л. 104. Род Рамодановских. \\
\hline 79. & $1633-39(1636)$ & Л. 37 об. Род князя Ивана Борятинскова. \\
\hline 80. & $1628-29$ & Л. 37 об. Род князя Дмитрея Петровича Пожарсково. \\
\hline 81. & 1629 & $\begin{array}{l}\text { Л. } 29 \text { об. Род боярина князя Афонасья Васильевича Лобанова. Князя Василия, княгиню Соломаниду, князя } \\
\text { Афонасия, княгиню иноку Александру, княгиню иноку Софию, княгиню Устину, князя Михаила, князя инока } \\
\text { Феодосиа (Л. 30) князя Симеона, княгиню иноку Марию, князя инока Патрекия, князя Ивана, Захария, } \\
\text { Аверкия убиен, Елену, князя инока Иону, княгиню иноку Марфу. } \\
\text { Л. 53. (Род боярина князя Афонасья Васильевича Лобанова. Княгиню иноку Софью, княгиню Устину, князя } \\
\text { Афонасия) })^{10} \text {. }\end{array}$ \\
\hline 82. & 1630 (?) & Л. 40 об. Род князя Петра Борятинскаго. \\
\hline
\end{tabular}

9 Запись зачеркнута в рукописи (ОР РНБ. Ф. 550. F.ІV.194. Л. 71 об. (76 об.)). Поминание, видимо, было ошибочно «продублировано» при переписке памятника.

10 Запись зачеркнута в рукописи с пометой: «писан впереди» (ОР РНБ. Ф. 550. F.IV.194. Л. 53 (58)). 


\begin{tabular}{|c|c|c|}
\hline № & Дата & Поминание \\
\hline 83. & 1631 & Л. 41 об. Род княгини Анисьи Петровны Шуйской. \\
\hline 84. & 1630 (?) & Л. 113 об. Род княгини Марфы Борятинской. \\
\hline 85. & $1630-31$ & Л. 114-114 об. Род князя Бориса Петровича Татева. \\
\hline 86. & 1633 & Л. 78. Род боярина Михаила Федоровича Кашина. \\
\hline 87. & 1633 & Л. 36 06.-37. Род боярина князя Дмитрия Михайловича Пожарского. \\
\hline 88. & 1633 & Л. 86 об. Род князя Луки Осиповича Щербатого. \\
\hline 89. & 1633 & Л. 140 об. Род князя Володимера Тимофеевича Долгорукова. \\
\hline 90. & 1635 (?) & Л. 33. Князя Григория Тюфякины. \\
\hline 91. & 1635 (?) & Л. 145. Род князя Васильевой княгини Трестенской. \\
\hline 92. & 1636 & Л. 146. Род князя Ивана Петровича Борятинского Маньки. \\
\hline 93. & 1636 & Л. 126. Род князя Ивана Михайловича Борятинского. \\
\hline 94. & $1634-65$ & Л. 240 об. Род окольничего князя Федора Федоровича Волконского. \\
\hline 95. & $1626-38(1638)$ & Л. 153. Род князя Михаила Васильевича Белосельскаго. \\
\hline 96. & $1630-33$ & Л. 216. Род князя Андрея князь Иванова сына Львова. \\
\hline 97. & $1630-33$ & Л. 217. Род князя Алексея Ивановича Козловского. \\
\hline 98. & $1633-39$ & Л. 221. Род князя Семена Каркадинова. \\
\hline 99. & $1636-37$ & Л. 229 (235). Род князя Савелия Ивановича Козловского. \\
\hline 100. & $1635-37$ & Л. 230. Род князя Федора Ивановича Щербатово. \\
\hline 101. & $1637-38$ & Л. 230 об. Род князя Василия Петровича Щербатаго. \\
\hline 102. & 1638 & Л. 41. Род князя Ивана Ивановича Шюскаго. Князя инока схимника Ионы. \\
\hline 103. & 1638 & Л. 66. Род князя Андрея Васильевича Елецкова. \\
\hline 104. & 1638 & Л. 241 об. Род князя Федора Андреевича Елецкова. \\
\hline 105. & 1639 & Л. 235 об. Род князя Афанасия Григорьевича Козловского. \\
\hline 106. & $1640-42$ & Л. 30 об. Род боярина князя Дмитрея Михайловича Пожарского. \\
\hline 107. & 1644 & Л. 253-253 об. Род болярина князя Юрия Андреевича Сицкаго. \\
\hline 108. & 1645 & $\begin{array}{l}\text { Л. 26. Лета } 7153^{11} \text { месяца февраля в } 25 \text { день Род боярина князя Бориса Михайловича Лыкова. Князя Васи- } \\
\text { лия, княгиню Ксению, князя Георгия, княгиню Устину иноку, князя Ивана, князя Михаила, убиенна на рати, } \\
\text { княгиню Евфимию, иноку Ефросинию схимницу, князя Петра младенца, княжну Агафью младенца, княжну } \\
\text { Ирину младенца, княжну Ульянею, князя Ивана младенца, княжну Акилину младенца, Васъсу иноку, } \\
\text { Варсунофью, Марфу, Дарию, князя Емельяна. }\end{array}$ \\
\hline 109. & $1640-45(1640)$ & Л. 254. Род князя Ивана Федоровича да князя Льва Волконских Веригиных. \\
\hline 110. & 1650-e (1651) & Л. 259 об. Род князя Ивана Федоровича Большого Шаховсково. \\
\hline 111. & $1649 / 50$ & Л. 260. Род князя Фомы Дмитриевича Мезецкова. \\
\hline 112. & 1655 & Л. 245 06. Род князя Василия Григорьевича Рамодановского. \\
\hline 113. & 1655 (?) & Л. 246. Род князя Григория Васильевича Тюфякина. \\
\hline 114. & $1647-50$ & Л. 260 об. Род князей Болховских. \\
\hline 115. & $1647-50$ & Л. 271-272. Род Микулинских Телятевских. \\
\hline 116. & $1653-55$ & Л. 261 об. Род князя Ивана Львовича Мосальского. \\
\hline 117. & 1650-e (1654) & Л. 299. Род Гагариных. \\
\hline 118. & $1650-1660$ & Л. 310 об.-311. Род старицы княгини Марфы Волконской. \\
\hline
\end{tabular}

11 В публикации А.И. Алексеева, вероятно вследствие опечатки, указан 7123 (1615), но в рукописи - 7153 (1645) (ОР РНБ. Ф. 550. F.IV.194. Л. 26 (32)), [3, с. 36]. 


\begin{tabular}{|c|c|c|}
\hline № & Дата & Поминание \\
\hline 119. & $1654-55$ & Л. 311 об. Род князя Семена Звенигородскаго. \\
\hline 120. & $1655-61$ & Л. 328 об. Род стольника князя Владимира Ивановича Волконского. \\
\hline 121. & $1640-1656(1655)$ & Л. 329 об. Род князя Симеона Иоанновича Шелешпанскаго. \\
\hline 122. & $1659-60$ & Л. 28. Род окольничего князя Семена Петровича Львова. \\
\hline 123. & $1662-87$ & Л. 37. Род князя Матфея, да князя Григория Аболенских. \\
\hline 124. & $1664-68$ & Л. 37 об. Род князя Никиты Яковлевича Львова. \\
\hline 125. & 1664 & Л. 51 об. Род князя Андрея Федоровича Мосальского. \\
\hline 126. & После 1648 (1664) & Л. 52. Род князя Матфея Ивановича Мышецкаго. \\
\hline 127. & $1654-55$ & Л. 318 об. Род князя Алексея Юрьевича Звенигородског. \\
\hline 128. & $1608-1670$ & Л. 140. Род князя Феодора Никитича Трубецкова. \\
\hline 129. & 1670 & Л. 335. Род князя Матвея Васильевича Прозоровскаго. \\
\hline 130. & 1670 & Л. 60. Род князя Семена да князя Матфея Прозоровских. \\
\hline 131. & 1670 & Л. 103. Род Щербатого князя Симеона. \\
\hline 132. & 1670 & Л. 336. Род стольника князя Григория Васильевича Оболенского Тюфякина. \\
\hline 133. & 1670 & Л. 23 об. Род боярыни княгини Екатерины Ивановны Трубецкие. \\
\hline 134. & 1670-e (1674) & Л. 334. Род князя Михаила Семеновича Шаховскова. \\
\hline 135. & $1665-87$ & Л. 144-144 об. Род князя Ивана Феодоровича Волконскаго. \\
\hline 136. & 1686 & Л. 53 об. Род князя Ивана Федоровича Волконского. \\
\hline
\end{tabular}

\section{Горбатые-Суздальские}

Первый выявленный автором случай княжеского вклада в ЧМ не включен в Табл. 1. Связан он с фамилией князей Горбатых. Боярин Михаил Васильевич Горбатый Кислый скоропостижно скончался весной 1535 г. в Москве после возвращения из похода во время Стародубской войны. Перед кончиной он успел постричься и принять схиму в ЧМ [18, с. 316]. В завещании М.В. Горбатый предписывал похоронить себя в Суздальском Рождественском соборе. Скорее всего, его воля была исполнена [12, с. 14-17], хотя Т.Д. Панова отметила князя М.В. Горбатого среди погребенных в ЧМ [16, с. 28]. В ЧМ, согласно завещанию князя, следовало дать 15 руб. ${ }^{12}$ В СЧМ поминания по нему нет, что может объясняться утратой большинства записей о вкладах и соответствующих поминаний за первую-вторую трети XVI в.

\section{Нагие-Оболенские}

Первым по времени княжеским вкладом, отмеченным СЧМ (Табл. 1. № 1), следует считать данный, повидимому, князем Иваном Андреевичем Нагим Лапиным Оболенским, который «жил у Троицы на Белых Песках», то есть постригся в Троицком Белопесоцком монастыре вблизи Каширы [21, ч. 1, с. 216], [36, с. 203-204]. В эту обитель он «вложил» вотчину в Коломенском уезде. Жало- ванная царская грамота на нее была оформлена в 1558 г. [15, с. 151-152]. Вклад от него в ЧМ мог поступить в 1538-1540 гг. Указанный временной промежуток определяется по датам двух его вкладов в ТСМ: 2 марта и 1 сентября 1538 г. [7, с. 58].

\section{Тулуповы}

Интересна поминальная запись князя Д. Тулупа Ряполовского (Табл. 1. № 6). Князь Данило в «Бархатной книге» не указан [21, ч. 2, с. 83], но генеалог XIX в. Г.И. Студенкин, составлявший роспись Тулуповых для «Русской родословной книги» А.Б. Лобанова-Ростовского, указал его сыном князя Ивана Васильевича Тулупова Немого с пометой «в черницах» [14, с. 298]. Вероятно, источником этих сведений послужил список с «Летописной редакции» родословной книги, в которой указан князь Данила «в черницах» [20, с. 39]. Поскольку эта редакция датирована М.Е. Бычковой 40-60-ми гг. XVI в. [5, с. 26-31] и в период ее создания князь Данило уже принял монашество, то вклад, данный им в ЧМ предположительно по жене и дочери, можно датировать 1550-1560 гг. По причине «ухода из мира» он не упоминался в Дворовой тетради, разрядах 1550-х [29, с. 41]. Указанный факт дает основание отнести его вклад в ЧМ к 1550 г. Место пострижения Д. Тулупова определенно назвать сложно. Это мог быть чМ или другая обитель (например, Суздальский Спасо-

12 «...приказщыки мои дадут в Суздаль, где мое тело грешное погребут, в собор Пречистой по мне и по нашых родителей село Павловское. А на Москве приказщики мои дадут к Михайлову Чюду да к Олексею чюдотворцу пятнатцать рублев» [2, с. 91-92]. 
Евфимьев монастырь).

\section{Сумские}

Вклад в ЧМ княгини Агрипены (Аграфены) Судской по дочери княгине Феодоре, бывшей женой князя Семена Дмитриевича Палецкого (Табл. 1. № 15) можно датировать 1562 г., поскольку тогда же ею был дан аналогичный вклад (100 руб.) в ТСM ${ }^{13}$.

\section{Ногтевы-Суздальские}

Одна запись СЧМ относится к младшей фамилии Суздальских Рюриковичей князьям Ногтевым (Табл. 1. № 21). В ней указана супруга князя Ивана Семеновича княгиня Анастасия, что устанавливается из памятника ТСМ. 13 июля 1568 г. в эту обитель поступил поминальный вклад 50 руб., который дала «княгиня Настасия князь Ивана Семеновича Ногтева» [7, с. 126]. На сколько княгиня Анастасия пережила супруга определить сложно. Заголовок записи СЧМ «Род по казенном диаке Непеи и княгине Анастасеи Нохтевы» указывает на ее происхождение из дьяческой фамилии. Дьяк Осип (Иосиф) Григорьев Непея служил в 1550-х-1570-х гг. [6, с. 135]. В материалах Н.П. Лихачева о родственных связях княжеских фамилий с семьями дьяков О. Непея и князья Ногтевы не упоминаются [13]. Нет сведений об их родстве и в специальном исследовании А.Ю. Савосичева [23]. Вклад в ЧМ, обеспечивавший поминание Анастасии Ногтевой, вероятно, поступил в 1570-х гг. Возможно, его сделал сам О. Непея. В другой записи СЧМ «Род казенного диака Иосифа Непеи» упоминаются Анастасия и инока Анастасия, но титул в обоих случаях отсутствует ${ }^{14}$.

\section{Шестуновы}

В СЧМ князья Шестуновы не упоминаются, но в ХК1586 отмечен вклад князя Федора Дмитриевича 12 июня 1586 г. 5 руб. братье на корм на крещение дочери княжны Акулины. Незадолго перед этим 8 июня он вернул ЧМ долг 100 руб., взятый в 7093 (1585/86) г. Возможно, заем был связан с его участием в посольстве и переговорах со шведами осенью 1585 г. [10, т. 10, стб. 31]. Через год 12 июня 1586 г. князю Ф.Д. Шестунову был послан «на благословение образ окладной Олексея Чюдотворца...на крещение дочери его Акилины» [35, с. 48, 145]. Вклады Ф.Д. Шестунова были недостаточными для «вечного» поминания и давались с иной целью.

\section{Шуйские}

В ХК1586 отмечен 1585/86 г. вклад князя Ивана Петровича Шуйского по «семье» княгине Марье «кубок серебрян двоичат позолочен сверху и внутри... Весу в кубке девять гривенок и тритцать шесть золотников. И за тот вклад семью его княгиню Марью в большой в литеиной и в братцкой и в кормовые книги написали, и душу ее нам в заупокойных молитвах поминати, и корм на братью на ее преставленье ставити ежегод безпереводно февроля в 3 день на память Семиона Богоприемца и Анны Пророчицы» [35, с. 44-45]. Этот вклад обусловил запись в СЧМ (Табл. 1. № 24). Хотя фамилия и боярский чин князя Ивана не указаны, но сведения ХК1586 позволяют с большой вероятностью «отождествить» его с известным военачальником, наиболее видным из князей Шуйских в 1580-х гг. боярином Иваном Петровичем.

Другая запись относится к князю Александру Ивановичу Шуйскому (Табл. 1. № 37). Брат будущего царя Василия князь Александр мог дать вклад в ЧМ по дяде князе В.Ф. Скопине, умершем около 1595 г. [22, т. 18, с. 593]. Сам Александр умер около 1601 г. [22, т. 23, с. 505-506]. Следовательно, вклад мог быть им дан в 1595-1600 гг.

Последняя запись Шуйских в СЧМ (Табл. 1. № 102) относится к февралю 1638 г., когда скончался последний князь этой фамилии боярин Иван Пуговка, принявший перед кончиной иночество и схиму ${ }^{15}$.

\section{Мосальские}

В СЧМ записано 4 поминания князей Мосальских (Табл. 1. № 25, 58, 116, 125).

В ХК1586 отмечен 7 марта 1586 г. крупный денежный вклад 100 руб. князя «Василиска» Васильевича Мосальского [35, с. 41]. При жизни князя надлежало «за его здравие Бога молити». Вкладчика, если бы он изъявил желание, следовало «постричи и в келье устроити, и покоити его до его живота как и протчую свою братию. А как бог по душу его сошлет, и нам его за тот вклад в Чюдове монастыре погрести честно и имя его в братцкой и во вседневной сенаник написати, и душу его в заупокойных молитвах поминати, и на его преставление корм на братью ставити ежегод безпереводно. И родители его в братцкой и во вседневной сенаник написали». Вклад можно датировать 1586-88 гг. В Боярском списке 1589 г. у имени князя Василия помечено: «В деревне, болен. Не быть, а взять с него людей по приговору» [32, с. 215]. Ве-

135 июня 1562 г. «Княгиня Огрофена князь Ивана Федоровича Суцкого по дочере княгине Феодоре князь Семенове Палецкого» $[7$, c. 67].

14 «Род казенного диака Иосифа Непеи. Инока Геннадия, Анастасию, Иосифа, инока Паисея, иноку Анастасию, Марию, иноку Евпраксею, Дарью» [3, с. 57].

15 Постригся 28.11.1637; умер в феврале 1638 г. [38, с. 457]. 
роятно, вскоре он скончался [8, с. 196, 203].

Вторая запись (Табл. 1. № 58) связана с князем Василием Михайловичем Рубцом Мосальским, поскольку упоминает о его чине боярина и дворецкого, которых никто другой из Мосальских не имел. Как ревностный сторонник первого Самозванца В.М. Мосальский получил от него боярство в 1605 г. Умер он около 1611 г. [8, с. 138-139].

Указанный в третьей записи СЧМ (Табл. 1. № 116) князь Иван Львович Клубков Мосальский в 1631/32 г. был воеводой в Галиче. Он служил в чине московского дворянина [17, с. 476] и скончался между 1653-55 гг., поскольку его поместья в 1655 г. были отданы племянникам $[8, \text { с. } 241]^{16}$. Следовательно, тогда же вклад по нему мог поступить в ЧМ.

Четвертая запись (Табл. 1. № 125) касается князя Андрея Федоровича Литвинова Мосальского. В 1611 г. он ездил под Смоленск от Семибоярщины и убеждал короля Сигизмунда идти к Калуге на Лжедмитрия II [8, с. 198199], [10, т. 12, прим. 703, стб. 126-127]. Окольничество он получил 25.07.1635 г. и умер в 7072 (1663/64) г. [38, с. 405]. Его поминальную запись в СЧМ можно датировать 1664 г.

\section{Барятинские}

В ХК1586 отмечен 6 мая 1586 г. вклад «Рожественного монастыря старицы» княгини Фетиньи Барятинской (Табл. 1. № 26) «образ штипядной Благовещения пречистой богородицы... И за тот ее вклад написали в сенаник четырнатцать имян родителей ее. А как бог по ее душу сошлет, и нам ее за тот же вклад в Чюдове монастыре похоронити и имя ее в братцкои сенаник написати, и душу ее в заупокойных молитвах поминати» [35, с. 46]. В СЧМ внесено пять поминаний Барятинских (Табл. 1. № 79, 82, 84, 92, 93), содержащих одно-два имени, что указывает на небольшие вклады в ЧМ, но запись с 14 именами «родителей» княгини Фетиньи отсутствует.

\section{Мстиславские}

«Индивидуальное» поминание (Табл. 1. № 67) последнего из князей Мстиславских боярина князя Федора
Ивановича можно датировать временем его кончины (19.02.1622 г.) [38, с. 414].

\section{Татевы}

Вклад, обусловивший поминальную запись Татевых (Табл. 1. № 85) можно датировать 1630-31 гг. Время вклада, «идентификацию» указанных в СЧМ лиц легко осуществить по памятникам ТСМ. В эту обитель, в которой располагалась усыпальница Татевых [31, с. 29-30], в 1630 г. было сделано несколько значительных вкладов вдовой Б.П. Татева княгиней Марией Михайловной (по происхождению княжной Лыковой) ${ }^{17}$. В поминальной записи СЧМ указаны: супруг княгини князь Борис, убитый в бою 3 мая 1607 г. под Калугой, их сыновья Федор и Иван (молитвенное имя Сергий), ${ }^{18}$ скончавшиеся почти одновременно в 1630 г., ${ }^{19}$ дочь Мария, умершая в начале того же $1630 r^{20}$

\section{ヘыковы}

Значительный вклад, судя по большому числу имен в поминании, был внесен в ЧМ боярином князем Б.М. Лыковым (Табл. 1. № 108). Его родитель князь Михаил Юрьевич указан как «князь Михаил, убиенный на рати» (погиб под крепостью Сокол в 1579 г.) [36, с. 246-249]. В поминании Б.М. Лыкова указано много имен князей и княжон, умерших в младенчестве. По-видимому, это его дети. Сам боярин князь Борис Михайлович скончался, не оставив потомства, 2.06.1646 г. [38, с. 409]. Отсутствием прямых наследников объясняются его крупные вклады в ЧМ, иные обители [36, с. 246-249]. В отличие от других вкладов в ЧМ, у данного Б.М. Лыковым, поставлена дата 25 февраля 7153 (1645) г.

\section{Гагарины}

Датировать вклад Гагариных, обусловивший запись в СЧМ князя Силы (Табл. 1. № 117), сложно, поскольку в их родословной князей с таким именем четверо и все носили отчество Иванович [21, ч. 2, с. 65-68]. Скорее всего, в СЧМ отмечен князь Сила Иванович, скончавшийся около 1647 г. Сохранилось «дело о записи за Марией Михайловой дочерью Хметевского, вдовой князя Силы Иванова сына Гагарина, по данной ее брата Астафия Михайлова сына Хметевского ее приданой вотчины» пустоши Ла-

16 Около 7161 (1652/53) г. он был по болезни от службы отставлен [4, с. 251].

17 «о князе Федоре Борисовиче Татеве дядя ево боярин князь Борис Михайлович Лыков да брат ево князь Иван Борисович Татев...100 рублев да 7 коней... по цене все за 70 рублев...1630 апреля 26» [7, с. 77].

185 июня 1630 г. «Княгиня Марья Михайловна Татева по сыне своем князе Сергие, прозвище Иване Борисовиче Татеве... аргамак бур....конь темносер....иноходец... по цене все 100 рублев. И за тот вклад тело сына ее князя Сергиево погребли у живоначальныя Троицы» [7, с. 77].

19 В Боярском списке 1629/30 г. отмечено: «Стольники... (Князь Федор да) - (в Вязьму). 138-го, апреля в 18 день умре - (князь Иван) - 138-го, мая в 26 день умре - (княж Борисов сын Татев)» [17, с. 329].

20 Князья Иван и Федор Борисовичи Татевы «по сестре своей княжне Марье Борисовне» внесли в ТСМ 50 руб. 6 февраля 1630 г. $[7$, C. 77] 
зарево в Каменском стане Дмитровского уезда (1647 г. февраля 7 - марта 12) [9, с. 1010-1011]. Возможно, Марья, пережившая на несколько лет супруга, постриглась и приняла схиму под именем Марфы. Согласно ее воле в ЧМ мог поступить вклад в 1650-х гг., обеспечивший запись ее и мужа в СЧМ. Отмеченное предположение косвенно подтверждает вклад в ЧМ Евстафия (Астафия) Хметевского. В соответствующую поминальную запись были включены князь Сила и княгиня Марфа схимница²1.

\section{Хилковы}

В ХК1586 отмечен вклад 5 руб. для «вписи в сенаник за князя Володимера за Хилкова» [35, с. 43], но в СЧМ записи князей этой фамилии отсутствуют. Внесенная сумма была недостаточной для «вечного» поминания и, скорее всего, по истечении определенного времени оно было вычеркнуто. Загадку представляет также личность самого князя Владимира, не указанного в родословной Хилковых [21, ч. 2, с. 77-79].

\section{Одоевские}

В ЧМ была погребена 4.01.1693 г. княгиня Ульяна Ивановна, вдова стольника Алексея Никитича Одоевского. Записи с ее именем в СЧМ нет, что объясняется прекращением ведения синодика к этому времени [3, с. 13]. Т.Д. Пановой отмечено также погребение в ЧМ князя Якова Никитича Одоевского 9.08.1697 г. [16, с. 49, 50].

\section{Куракины}

В ЧМ были похоронены в 1625-1684 гг. несколько князей и княгинь Куракиных, но соответствующих записей в СЧМ нет. Эта обитель была их усыпальницей и в XVIII в. [16, с. 37, 41, 44, 46, 50, 51, 54, 58, 59, 61, 67-68].

Из-за отсутствия дополнительных сведений и заголовка поминание «княгиню иноку схимницу Улею, Елену схимницу, княжну Анну девицу, во иноцех князя Алексея, иноку княгиню Феодосью, иноку Елену схимницу» не удалось связать с какой-либо фамилией. А.И. Алексеевым оно отнесено к заголовку «Род Федорова сына Огорева» [3, с. 89]. Согласно «родословной легенде» предок Огаревых «мурза честен именем Муталамамет, прозвище Огар» выехал из Золотой Орды на службу к великому князю Александру Невскому и крестился в православную веру [37, с. 300-303]. В XVI - первой трети XVII в. Огаревы числились в московских дворянах или в «служилых городах». Их социальный статус не был зна- чительным. Земельные владения Огаревых включали небольшие поместья и вотчины в Медынском, Костромском, Вологодском, Московском, Боровском, Дмитровском и других уездах [33, с. 164-165] $]^{22}$. Несмотря на невысокое общественное положение они могли породниться с какой-либо княжеской фамилией. С другой стороны, большое число титулованных имен в поминальной записи СЧМ нехарактерно для подобных случаев и вопрос о ее принадлежности к нетитулованной или княжеской фамилии нельзя считать решенным.

Еще две записи с утраченным заголовком содержат имена князей, княгинь, княжон, но относятся они к нетитулованной или княжеской фамилиям, автору установить не удалось [3, с. 97-98, 166].

Более чем в 80 записях СЧМ поминания князей встречаются у нетитулованных родов (Морозовы, Захарьины-Юрьевы-Романовы, Траханиотовы, Стрешневы, Воейковы, Плещеевы, Хлоповы, Унковские, Измайловы, Бутурлины, Грамотины, Вельяминовы, Сукины, Апраксины, Пивовы, Клешнины, Безобразовы и др.), что указывает на родство с княжескими фамилиями [3, с. 32-194]. Выше рассмотрен подобный случай Хметевских и князей Гагариных, отразившийся в записях СЧМ. Выяснение, с кем из князей породнились лица нетитулованных фамилий, требует специальной работы, выходящей за рамки настоящей статьи, и не во всех случаях для этого имеется достаточно данных ${ }^{23}$.

\section{$* * *$}

В сохранившихся актах ЧМ почти не упоминаются княжеские земельные пожалования ${ }^{24}$. Это можно объяснить отчасти мерами правительства по ограничению роста монастырского землевладения. Большинство поминаний в СЧМ были обусловлены денежно-вещевыми вкладами. О некоторых из них, сохранившиеся в ХК1586, сведения приведены выше. Данный вывод, конечно, требует уточнения и обоснования в рамках специального изучения происхождения и эволюции вотчинных комплексов ЧМ в разных уездах. Все же, по аналогии с другими обителями можно констатировать, что большинство княжеских вкладов делалось деньгами и вещами, а земли отдавались редко [27, с. 359-360], [30, с. 142].

Среди княжеских фамилий, записанных в СЧМ, преобладают первостепенные, но есть несколько малозначительных - князья Мышецкие, Болховские и др. (Табл.

21 «Род Евстафия Хметевскова. Ионы схимника, Евдокеи, Михаила, Евдокеи, Григория, Мавры, князя Силы, княгиню Марфу схимницу. Парасковии, Иоанна, Лазоря» [3, с. 185].

22 ОР РНБ. Ф. 550. F.IV.427. Писцовая книга. Л. 118 об.-119 об.; 205-207; 247 об.-249 об.; 273 об.-274; $282-284$.

23 «Расшифровка» одной из подобных записей на примере поминания Годуновых приведена А.И. Алексеевым [3, с. 184, прим. 926].

24 Единственный пример 1556/57 г., относящийся к князьям Тростенским, не был «княжеским», поскольку обеспечивал поминание нетитулованных Лелечиных [11, с. 116-118, 120]. 
1. № 114, 126). Вкладчиками ЧМ были лица входившие в состав Государева двора, часто бывавшие в Москве. В отдельных случаях сохранились сведения о вкладах, данных в ЧМ, но соответствующих записей в СЧМ нет. Примерами утраты значительной части поминаний могут служить рассмотренные выше случаи княгини Фетиньи Барятинской, князя С.Д. Щербатого.

В СЧМ почти не упоминаются фамилии князей кабардинских, ногайских, татарских, хотя в крупные монастыри князья Шейдяковы, Черкасские и др. вклады давали. Является указанное обстоятельство случайностью или нет - определенно решить сложно. Как исключение следует отметить запись в СЧМ «Род князя Феодора Мелегдаировича» (Долголяцкого). Казанский царевич князь Федор был связан свойством с ветвью князей Ростовских и удельных князей Волоцких [3, с. 109].

Немало поминаний княжеских фамилий содержат имена князей, княжон, умерших в младенчестве и не попавших в родословные. Эти сведения уникальны, поскольку их нет в других источниках. Столь же ценны данные о составе женской части фамилий.

Можно констатировать, что временной диапазон княжеских вкладов в ЧМ охватывает 1538-1680-е годы и наибольшее их количество пришлось на период 15861655 гг. (Табл. 1. № 24-121). Указанная динамика не согласуется с аналогичными «показателями» по другим обителям, в которых максимум княжеских вкладов отмечен во второй трети XVI в., а в последних десятилетиях XVI - первых XVII в. -существенный спад, и с середины 1620-х гг. - новый подъем [25, с. 61], [27, с. 359], [30, с. 133]. Скорее всего, «своеоборазие» динамики чМ отражает плохую сохранность данных о княжеских вкладах за первую-вторую трети XVI в. Иными словами, до нас дошли сведения примерно о 30-35\% вкладов и обусловленных ими поминаниях. Вместе с тем, нельзя исключить другие объяснения данного факта [3, с. 10]. Для более основа- тельной его интерпретации необходимо специальное изучение вкладов княжеских фамилий в столичные монастыри и сопоставление их с данными по ЧМ и другим обителям Московского государства. Возможно, в сравнении с «региональными» столичные монастыри имели особенности, отразившиеся в динамике княжеских вкладов, составе вкладчиков.

В настоящей работе вопрос «идентификации» по родословным лиц, включенных в поминания СЧМ, освещен мало, поскольку основная цель заключалась в датировке записей. А.И. Алексеев отчасти решил эту задачу в комментариях к публикации текста данного памятника, но немало неясных случаев осталось. Автор надеется в будущем посвятить этой проблеме отдельные работы. Заслуживают специального исследования процессы формирования и эволюции «вотчины» чМ, кратко охарактеризованные А.И. Алексеевым [3, с. 9]. Особым сюжетом может стать изучение деятельности архимандрита Левкии в середине XVI в. [3, с. 10]. Наряду с работами С.Н. Богатырева, Т.Д. Пановой, А.В. Антонова, С.Н. Кистерева и др., посвященных отдельным памятникам ЧМ, несомненно, важное значение для исследователей имеет публикация текста СЧМ, осуществленная А.И. Алексеевым. Опыт плодотворного использования данных этого ценнейшего источника при изучении биографий князей Оболенских содержит монография О.И. Хоруженко [36, С. 200, 216].

В отечественной исторической науке успешно развивается направление по изучению истории монастырей Русского государства. Объектами исследования историков разных поколений стали обители, имевшие общерусское значение, и «региональные». ЧМ в данном перечне отсутствует, но к его памятникам на протяжении десятилетий существует устойчивый интерес ученых и можно надеется на появление со временем специального посвященного ему исследования.

\section{ЛИТЕРАТУРА}

1. Акты социально-экономической истории Северо-Восточной Руси. М., 1964. Т. 3.

2. Акты Суздальского Спасо-Евфимьева монастыря 1506-1608 гг. / Сост.: С.Н. Кистерев, Л.А. Тимошина. М., 1998.

3. Алексеев А.И. Синодик Чудова монастыря в Московском Кремле // Вестник церковной истории. М., 2019. Вып. 3/4 (55/56). С. 5-239.

4. Белоусов М.Р. Боярские списки 1645-1667 гг. как исторический источник. Казань, 2008. Т. 1.

5. Бычкова М.Е. Родословные книги XVI-XVII вв. как исторический источник. М., 1975.

6. Веселовский С.Б. Дьяки и подьячие XV-XVII вв. М., 1975.

7. Вкладная книга Троице-Сергиева монастыря. М., 1987.

8. Власьев Г.А. Потомство Рюрика. Материалы для составления родословий. СПб., 1906. Т.1. Ч. 1.

9. Записные вотчинные книги Поместного приказа 1626-1657 гг. М., 2010.

10. Карамзин Н.М. История государства Российского. М., 1989. Кн. 3. Т. 9-12.

11. Кистерев С.Н. Акты Московского Чудова монастыря 1507-1606 годов // Русский дипломатарий. Вып. 9. М., 2003. С. $59-234$.

12. Курганова Н.М. Страницы истории некрополя города Суздаля. М., 2004. 
13. Лихачев Н.П. Родственные связи княжеских фамилий с семьями дьяков. ИРГО. СПб., 1900. Вып. 1. Отд. І. С. 114-119.

14. Лобанов-Ростовский А.Б. Русская родословная книга. СПб., 1895. Т. 2.

15. Описание грамот Коллегии экономии. К-Р / [подгот. А.В. Антонов]. М., 2018.

16. Панова Т.Д. Некрополи Московского Кремля. М., 2010.

17. "Подлинные" боярские списки 1626-1633 годов: сборник документов / сост. Е.Н. Горбатов. М., 2015.

18. Полное собрание русских летописей. Т. 26. М., 1959.

19. Полное собрание русских летописей. Т. 34. М., 1978.

20. Редкие источники по истории России. Вып. 2. М., 1977.

21. Родословная книга князей и дворян российских и выезжих..., которая известна под названием Бархатной книги. М., 1787. Ч. 1-2.

22. Русский биографический словарь. Т. 18. Сабанеев-Смыслов. СПб., 1904; Т. 23. Шебанов-Шютц. СПб., 1911.

23. Савосичев А.Ю. Дьяки и подьячие XIV-XVI веков: дисс. док. ист. наук: 07.00.02. Орел, 2015.

24. Сергеев А.В. Княжеские фамилии Московского государства XVI-XVII вв.: количество, время существования, социальный статус. // Клио. 2018 . № 2. C. 39-49.

25. Сергеев А.В. Письменные памятники Ярославского Толгского монастыря как источник биографических сведений о представителях княжеских фамилий Московского государства XVI-XVII вв. // История и культура Ростовской земли. 2017. Ростов, 2018. С. 45-62.

26. Сергеев А.В. Представители княжеских фамилий XVI-XVII в. во вкладных и кормовых монастырских книгах из коллекции А.А. Титова // История и культура Ростовской земли. 2014. Ростов, 2015. С. 75-84.

27. Сергеев А.В. Представители княжеских фамилий Московского государства XVI-XVII веков во вкладных книгах Иосифо-Волоколамского монастыря // Преподобный Иосиф Волоцкий и его обитель: Сб. статей. Вып. 4. М., 2017. С. 326-374.

28. Сергеев А.В. Сведения о представителях княжеских фамилий Московского государства XVI-XVII вв. в письменных памятниках Чудова монастыря // Комплексный подход в изучении Древней Руси. Сборник материалов Х Международной научной конференции (9-13 сентября 2019 г., Москва, Россия). Приложение к журналу «Древняя Русь. Вопросы медиевистики». М., 2019. С. 181-182.

29. Сергеев А.В. Стародубские Рюриковичи в Тысячной книге 1550 г. и Дворовой тетради начала 1550-х гг. // Клио. 2018. № 8. С. 36-48.

30. Сергеев А.В. Троице-Сергиев монастырь и княжеская аристократия Московского государства в XVI-XVII в.: виды и динамика вкладов // Троице-Сергиева Лавра в истории, культуре и духовной жизни России: материальные свидетельства духовной культуры. Сборник материалов IX международной конференции 16-17 октября 2014 года. Сергиев Посад, 2016. С. 132-143.

31. Список погребенных в Троицкой Сергиевой Лавре, от основания оной до 1880 года. Нижний Новгород, 2012.

32. Станиславский А.Л. Труды по истории государева двора в России XVI-XVII вв. М., 2004.

33. Сташевский Е.Д. Землевладение московского дворянства в первой половине XVII века. Нижний Новгород, 2012.

34. Стрельников С.В. Особенности редактирования вкладных и кормовых книг Ростовского Борисоглебского монастыря // Опыты по источниковедению. Древнерусская книжность: редактор и текст. СПб., 2000. Вып. 3. С. 305-322.

35. Хозяйственные книги Чудова монастыря 1585/86 г. / Сост. С.Н. Богатырев. М., 1996.

36. Хоруженко 0.И. Историческая география Оболенского уезда XVII-XVIII веков. М., 2019.

37. Шабаев Л.Е. Родословные росписи, поданные в Палату родословных дел в конце XVII в. // Российская генеалогия: научный альманах. Вып. 7. М., 2020. C. 269-423.

38. Poe M. The Russian Elite in the Seventeenth Century. Helsinki, 2004 . Vol. 1.

(c) Сергеев Антон Вадимович (sergeev1967@inbox.ru). 